\section{Growing Apples for Hard Cider Production in the United States-Trends and Research Opportunities}

\author{
Carol A. Miles ${ }^{1}$, Travis R. Alexander ${ }^{1}$, Gregory Peck $^{2}$, \\ Suzette P. Galinato ${ }^{3}$, Christopher Gottschalk ${ }^{4}$, \\ and Steve van Nocker ${ }^{4}$
}

ADDITIONAL INDEX WORDs. alcohol, beverage industry, fermentation, high density, Malus, phenolics, tannins

Summary. Hard cider, made by fermenting apple (Malus $\times$ domestica) juice, was at one time the most widely consumed alcoholic beverage in America. Largely abandoned after Prohibition, within the past 2 decades the rise in popularity of craft beverages has led to the reemergence of hard cider as an alternative to beer, wine, and spirits. Today, hard cider represents one of the fastest growing sectors within the craft beverage industry. The recent interest in cider presents additional marketing opportunities for apple growers and businesses currently involved in, or considering entering, the apple cider or craft beverages industries. However, the lack of a strong history or experience in selecting, producing, and using cider apples poses a significant challenge to this emerging market. This article reviews the current state of research in cider apple production, including economic feasibility, mechanized management, and cultivar evaluation and improvement.

$\mathrm{C}$ urrent demands for diverse, natural, and locally produced beverages have resulted in the reappearance of hard apple (Malus $\times$ domestica) ciders in food markets, restaurants, and bars. In 2018, revenues from hard cider, perry [fermented

Received for publication 3 Sept. 2019. Accepted for publication 21 Jan. 2020.

Published online 20 February 2020.

${ }^{1}$ Washington State University, Northwestern Research and Extension Center, 16650 State Route 536, Mount Vernon, WA 98273

${ }^{2}$ Cornell University, School of Integrative Plant Science - Horticulture, 135 Plant Science Building, Ithaca, NY 14853

${ }^{3}$ Washington State University, IMPACT Center, P.O. Box 646214, Pullman, WA 99164

${ }^{4}$ Michigan State University, Department of Horticulture and Graduate Program in Plant Breeding, Genetics \& Biotechnology, 1066 Bogue Street, East Lansing, MI 48824

We thank Jaqueline King and Ed Scheenstra for their contributions to this work. This research was supported by the following funding sources: Washington State Department of Agriculture Specialty Block Grant Project No. K1270, Michigan Department of Agriculture and Rural Development Specialty Block Grant Project No. 190000000321, Washington State University Emerging Research Issues Grant \#15-01-02, and National Institute of Food and Agriculture, U.S. Department of Agriculture, Hatch Grants (Accession No. 1000194, 1014042, and 1020463)

S.V. is the corresponding author. E-mail: vannocke@ msu.edu.

This is an open access article distributed under the CC BY-NC-ND license (https://creativecommons.org/ licenses/by-nc-nd/4.0/).

https://doi.org/10.21273/HORTTECH04488-19 pear (Pyrus sp.) juice], and rice (Oryza sativa) wine in the United States exceeded \$2.2 billion (Degenhard, 2019). In the period 2010-18, per capita consumption of specialty drinks including cider increased $487 \%$, even as consumption of beer showed an overall decline. This trend is anticipated to continue at least through 2023 from specialty drinks, including hard cider, is predicted to increase from 2019 at least until 2023, in spite of a decline in revenue growth for alcoholic beverages as a whole (Statista, 2019a). Currently, hard cider is preferred by young-adult drinkers; nearly 3 -fold more Americans in the age range 18 to 29 years consume cider than those 50 to 64 years old (Statista, 2018). In contrast, consumption of white and red wine is similar between the two age groups (Statista, 2019b, $2019 \mathrm{c}$ ). Thus, as the younger generation ages, the prospect that hard cider (Degenhard, 2019). Revenue growth may be reestablished as a standard drink in the United States in the coming decades seems strong.

These impressive statistics supporting a growth market in hard cider may entice apple growers to change at least part of their operations to focus on apple production for hard cider. Such a decision typically will be based on economic considerations, including not only the current and projected market for hard cider, but also the cost of establishing and producing specialty cider apple cultivars. Such cultivars may have horticultural needs that are very different from freshmarket apple, requiring growers to adapt or remodel their current management practices.

For cider producers, a paramount factor in the decision to use specialty cider apples is the expense of sourcing fruit and juice from such cultivars. These specialty cultivars produce juice with one or more biochemical qualities that facilitate production of a highquality hard cider, including high sugar, high acid, a phenolics content that enhances "mouth feel" and promotes stability during storage, and good flavor that persists through fermentation. Currently, finding specialty cider apples is a significant challenge for U.S. cider producers (Pashow and Mahr, 2018). This supply-side challenge potentially limits cider sales, especially for products in the higher price points, but also offers apple growers an opportunity to charge a significant premium for a specialty crop.

However, the use of specialty cider fruit/juice does not appear to be necessary in the current market. Much of the $\approx 50$ million gallons of hard cider currently produced in the United States is made from imported apple juice concentrate and/or inexpensive fresh-market or processing fruit (often fruit that did not meet fresh-market standards). Our conversations with cider producers in at least two states suggest that products with

\begin{tabular}{llll}
\hline $\begin{array}{l}\text { Units } \\
\text { To convert U.S. to SI, } \\
\text { multiply by }\end{array}$ & U.S. unit & SI unit & $\begin{array}{l}\text { To convert SI to U.S., } \\
\text { multiply by }\end{array}$ \\
\hline 0.4047 & $\mathrm{acre}(\mathrm{s})$ & $\mathrm{ha}$ & 2.4711 \\
0.3048 & $\mathrm{ft}$ & $\mathrm{m}$ & 3.2808 \\
3.7854 & $\mathrm{gal}$ & $\mathrm{L}$ & 0.2642 \\
0.4536 & $\mathrm{lb}$ & $\mathrm{kg}$ & 2.2046 \\
1.1209 & $\mathrm{lb} / \mathrm{acre}$ & $\mathrm{kg} \cdot \mathrm{ha}^{-1}$ & 0.8922 \\
$\left({ }^{\circ} \mathrm{F}-32\right) \div 1.8$ & ${ }^{\circ} \mathrm{F}$ & ${ }^{\circ} \mathrm{C}$ & $\left({ }^{\circ} \mathrm{C} \times 1.8\right)+32$
\end{tabular}


the largest market share include specialty cider cultivars as only a minor ingredient, if at all. Probably the most important component contributed by specialty cultivars is phenolics, which serve as a preservative, allowing cider to be stored for long periods. This feature was particularly useful in colonial times when cider was stored in wood barrels and the antimicrobial and antioxidant effects of sulfur dioxide were not well understood. This role for apple phenolics has been largely supplanted by more efficient fruit storage conditions, less permeable storage containers, and the higher alcohol level that can be produced by specialized wine yeasts ( $S a c^{-}$ charomyces cerevisiae). Still, attributes associated with traditional cider may influence how much a consumer is willing to pay for the product (Tozer et al., 2015). As cider becomes more popular, a diversity of products with more body, taste, and aroma may be sought after, and this would augment the need for specialty cultivars and juice (Gottschalk et al., 2017).

Ultimately, the transition to, or expansion of, hard cider operations, whether by growers or cider producers, would best be founded on a solid body of research, focusing not only on the economic considerations involved, but also the horticultural sustainability of cider apple production. The purpose of this review was to provide an update on the current research status of cider apple production in the United States.

\section{Economic considerations in cider apple production}

For apple orchard operations, profitability is influenced by installation and operational costs, fruit yield, and the price of the produce. Case studies in Washington, New York, and Virginia have provided growers with feasibility assessments of producing cider apples, as well as estimates of operating costs and returns (Farris et al., 2013; Galinato and Miles, 2016; Galinato et al., 2014; Peck and Knickerbocker, 2018). Key cider apple growers and industry experts in these states were surveyed to develop baseline budgets that reflect the local environmental and economic conditions (Table 1 ). These studies confirmed that, in the long run, revenues for the operations did exceed production costs, with "payback periods" (when net cumulative returns became greater than initial investment and cumulative operating costs) of 10 to 16 years (Table 1$)$. In all four regions, labor cost was the most significant operating expense, contributing $\approx 65 \%$ of variable costs in Virginia and 62\% to 76\% in Washington. Labor costs have recently been exacerbated by increases in minimum wage rates (for example, up to $\approx \$ 15$ per hour for agricultural workers in Washington state) and increasing scarcity of labor (Economics Policy Institute, 2019).

\section{Production systems}

An orchard is typically a 20 - to 30 -year investment, and thus a crucial component of a new cider apple operation is the type of production system to be used. Traditionally, both in the United States and abroad, cider apple was grown in low-density (70-100 trees/acre) orchards, on rootstocks that support vigorous growth and produce a free-standing tree. However, in Europe and elsewhere, many cider apple growers have shifted to higher-density systems using semidwarfing rootstocks that allow for a greater degree of mechanization
(Fitzgerald et al., 2013). Many cider apple growers in the United States are transitioning to high-density (10001500 trees/acre or more) systems using dwarfing rootstocks that are now standard for new plantings of fresh-market cultivars. The benefits of these more intensive production systems for freshmarket apple production include greater precocity (full production is obtained 3 to 5 years after planting), better fruit quality, reduced biennial bearing, better spray coverage, and greater labor efficiency (Robinson et al., 2013). However, for cider apple, potential benefits of the highest-density production systems (e.g., >1000 trees/acre) have not been demonstrated. In fact, an economic evaluation of six cider apple orchards in New York determined that the highest-density orchard was the least likely to obtain profitability within 25 years after planting (Peck and Knickerbocker, 2018). The overriding factor was the cost of installation, which for high-density plantings can exceed $\$ 20,000$ per acre (Merwin, 2015). However, these and other longterm profitability estimates for orchard operations are obviously strongly influenced by fruit price, which is in turn strongly influenced by demand. Clearly, more studies are needed to develop costeffective cider apple orchard systems.

\section{Preharvest and postharvest factors that affect cider quality}

Most horticultural research on apples has focused on quality attributes that are important for freshmarket fruit, such as yield, fruit size and color, physiological disorders, and storage length. Conversely, for wine grape (Vitis sp.), considerable research has been conducted to increase wine quality by improving the physiological and nutritional status of grapevines. For cider apples, little

Table 1. Features, costs and returns of cider apple production in New York, Virginia, and Washington.

\begin{tabular}{lcccc}
\hline & New York & Virginia & Central Washington & Western Washington \\
\hline Orchards surveyed $($ no. & 6 & 10 & 2 & (not reported) \\
Density (trees/acre $)^{\mathrm{z}}$ & 726 & 581 & 1,452 & 726 \\
Labor cost $(\$ / \text { acre })^{z, y}$ & 2,592 & 2,100 & 5,360 & 6,730 \\
Chemical cost $(\$ / \text { acre })^{y}$ & 727 & 730 & 940 & 280 \\
Yield $(1 \mathrm{~b} / \text { acre })^{z, y}$ & 34,050 & 37,200 & 45,000 & 41,400 \\
Gross return $(\$ / \mathrm{lb})^{\mathrm{z}}$ & 0.45 & 0.36 & 0.35 & 0.35 \\
Annual net return $(\$)$ & 10,206 & 7,700 & 3,810 & 1,570 \\
Payback period (years) & $10^{\mathrm{x}}$ & 10 & 12 & 16 \\
Citation & Peck and Knickerbocker $(2018)$ & Farris et al. $(2013)$ & Galinato and Miles (2016) & Galinato et al. (2014) \\
\hline
\end{tabular}

${ }^{\mathrm{z}} \mathrm{l}$ tree $/ \mathrm{acre}=2.471 \mathrm{l}$ trees $/ \mathrm{ha}, \$ 1 / \mathrm{acre}=\$ 2.471 \mathrm{l} / \mathrm{ha}, \mathrm{llb} / \mathrm{acre}=1.1209 \mathrm{~kg} \cdot \mathrm{ha}^{-1}, \$ 1 / \mathrm{lb}=\$ 2.2046 / \mathrm{kg}$.

$\mathrm{P}$ Per year, at full production.

${ }^{\mathrm{x}}$ Mean for five orchards. One operation would not have achieved profitability even within 25 years. 
research has been devoted to the influence of preharvest practices on hard cider quality. This is in part because, in Europe, cider apples have traditionally been grown for processing, with minimal inputs, and fruit from many different orchards are often homogenized into a uniform product by blending and/or concentrating the juice.

Nitrogen $(\mathrm{N})$ is not only important for apple tree growth and productivity, but also a necessary nutrient for yeast during fermentation. Total yeast assimilable $\mathrm{N}$ (YAN), the fraction of $\mathrm{N}$ that can be metabolized by yeast, in juice from cider apples was found to be appreciably lower than that required for optimal fermentation (Valois et al., 2006). Although Valois et al. (2006) found little effect of $\mathrm{N}$ fertilization on YAN in the juice, Peck et al. (2016) found that reduced crop load was associated with increased YAN. However, YAN concentration in juice from the lowest crop load trees evaluated was still much lower than optimal. Ma et al. (2018) determined that there are unique amino acid compositional fingerprints of apple cultivars, suggesting, as is the case with wine grape, that $\mathrm{N}$ management strategies for cider apple may be genotype-specific. Pedioclimatic factors may be interactive with $\mathrm{N}$ uptake and partitioning within apple trees; this research area deserves additional attention.

An increasing area of focus for cider apple growers in drier areas of the United States is regulated deficit irrigation (RDI), which has been shown to influence fruit quality attributes in fresh-market apples. Mpelasoka et al. (2001) demonstrated a decrease in fruit size and an increase in the dry matter concentration, firmness, and total soluble solids (TSS) of 'Braeburn' in response to RDI. Although a reduction in fruit size is not desirable for freshmarket apples, it could have a positive effect on cider apples. Miles et al. (2017) attributed decreased tannin levels of three cider apple cultivars grown in Washington State vs. Bristol, England to more intense water and nutrient management of orchards in the former region. Greater firmness is desirable for cider apples because firmer fruit produces particles with a greater ratio of surface area to volume when milled, which allows for more efficient pressing (Root and Barrett, 2005).
Achieving a higher polyphenol concentration with less apple tissue could also reduce waste generation in the milling and pressing. A greater TSS content is favorable for cider apples, as more sugar increases the potential alcohol-by-volume percentage in the final fermented product. Researchers at Washington State University (WSU), led by Dr. Carol A. Miles, have initiated a study evaluating RDI in cider apple orchards for improved water use efficiency, reduced labor input, and improved fruit quality.

The potential to increase polyphenol concentration in apples is of interest to both the fresh-market industry and the cider industry, because many of these compounds are antioxidants and are considered to have nutraceutical benefits for human health. Based on a study using potted apple trees grown in sand, Lea and Beech (1978) found that increasing nitrogen fertilizer rate could negatively affect polyphenol content. However, neither nitrogen fertilization nor yield affected juice polyphenol content in orchard-soil-based studies (Peck et al., 2016; Unuk et al., 2006). Ongoing research in the Peck Laboratory at Cornell University is further exploring the effects of $\mathrm{N}$ and crop load on polyphenols.

Postharvest handling of fruit destined for cider also differs between the United States and the major cider-producing countries of western Europe. In Europe, mechanically harvested fruit is often left outside on the ground or on concrete pads until the cider producer is able to transport it to the cidery. These apples may be left outdoors for days or even weeks. In the United States, harvested fruit is generally stored in large refrigerated rooms for many months, often in controlled atmosphere storage where temperature, humidity, oxygen, and carbon dioxide are monitored. This practice is driven by established storage regimens for fresh-market apples, and concerns about contamination with patulin (a mycotoxin produced in moldy apples). Ewing et al. (2019) found minimal impact on juice or cider polyphenols over a 1-month harvest interval, but note that an increase in fruit storage time and temperature resulted in softer fruit, increased juice TSS, and decreased juice acidity. Total polyphenol concentration in juice increased with fruit storage time and temperature. Ciders made with the cultivars Dabinett and Binet Rouge had higher levels of polyphenols and flavanols (the class of polyphenols responsible for imparting bitterness and astringency) when fruit was stored for 6 weeks at $10{ }^{\circ} \mathrm{C}$, as compared with 4 months at $1{ }^{\circ} \mathrm{C}$ (Ewing et al., 2019). These increases may be attributed to concentration by fruit dehydration. The mechanism and repeatability of this effect warrants further research, as many U.S. cider producers are using fruit that has been stored for long periods of time.

\section{Mechanization}

The future availability of agricultural workers to prune trees and pick fruit is a concern for the entire apple industry. Thus, just as with freshmarket apple, a sustainable long-term production strategy for cider apple may include mechanization for labor-intensive tasks such as fruit thinning, pruning, and harvesting. Paramount among these is harvesting; harvesting by hand can account for $30 \%$ or more of the cost of production (Farris et al., 2013; Klonsky and Stewart, 2014; Miles and King, 2014). Strategies for mechanical harvesting of cider apples might differ significantly from those for freshmarket apples; because the fruit is made into juice, punctures and bruises from the trauma of mechanical harvesting might be acceptable. However, postharvest storage life would be significantly reduced (Alexander et al., 2016a). In addition, because the alcohol in the fermented product should suppress microbial growth, it may eventually become acceptable to recover dropped fruit from the orchard floor for cider use (Ewing and Rasco, 2018; U.S. Food and Drug Administration, 2001).

In the traditional cider orchards in Europe, fruit is harvested mechanically with equipment that shakes fruit off the trees and then sweeps it from the orchard floor. This "shake-and-sweep" method of harvesting is enabled by the sturdy, self-supporting trees with adequate root anchorage that can withstand the clasping and vigorous shaking action of the equipment. For trees on semidwarfing and dwarfing rootstocks, mechanical harvesting approaches are still under development and have not yet been adopted widely. In the United 
States, both over-the-row and shakeand-catch harvesting equipment is used for other tree fruit and nut crops, and may be adapted for harvesting of cider apples. Researchers at WSU's Northwestern Washington Research and Extension Center (NWREC, Mount Vernon, WA) have been assessing the use of over-the-row, "shake-andcatch" mechanical harvest systems and their impact on cider apple production since 2011 (Alexander et al., 2019; Miles, 2017). In one study, use of a small over-the-row blueberry (Vaccinium sp.) harvester for a specialty cider cultivar reduced harvest costs up to $22 \%$ relative to hand harvesting (Galinato et al., 2016), with negligible impact on juice quality at harvest or after 1 month of cold storage (Miles and King, 2014). Alexander et al. (2018) demonstrated that harvesting method (i.e., machine vs. hand-harvest) did not affect total phenolics and tannins, but did influence sensory attributes, of the resulting cider.

Precision mechanical harvesting will require reliable and highthroughput methods to assess fruit maturity, which for cider apples can be very different from fresh-market apples. Currently, growers use a variety of subjective measures to assess maturity, including perceived sweetness, astringency and bitterness, TSS, starch, skin color, seed color, firmness, and extent of fruit drop. Researchers at the NWREC are testing hand-held, nondestructive meters as a reliable method to accurately and repeatedly measure fruit maturity. One of these, the Produce Quality Meter (F750; Felix Instruments, Camas, WA) uses near-infrared (IR) spectroscopy to estimate quality metrics, such as color, dry matter content, TSS, and titratable acidity. Another, the Delta Absorbance meter (53500; T.R. Turoni, Forlì, Italy) uses visible and near-IR spectroscopy to measure chlorophyll content.

In contrast to mechanical harvesting, there have been no studies of mechanical strategies for flower or fruit thinning, or pruning, that pertain uniquely to cider apple production. New labor-saving orchard systems may provide growers with long-term economic benefits, but these systems need to be tested in different environments and with various orchard management practices. A serious drawback for the use of mechanization is that trees must be highly uniform in architecture and fruiting habit. This is typically obtained only in intensive medium- and high-density plantings, which require high up-front investment. In addition, mechanization requires purchase or rental of potentially expensive equipment. Further studies of the economic efficacy of mechanization are thus warranted, especially focusing on specialty apple cultivars.

Cider apple research orchards have been established in several states. For example, in 2016, a replicated medium-density orchard with 65 cider apple cultivars was established at the NWREC. In New York, Cornell researchers have established nearly 3 acres of high-density cider apple orchards since 2015. At Michigan State University (MSU)-sponsored facilities in Michigan, more than 60 cultivars are being grown in both low- and high-density orchards. Collectively, these and other planting that are being established around the country will provide new ideas about how to profitably manage cider apple orchards to produce high yields of quality fruit.

\section{Identification and evaluation of apple cultivars for hard cider use}

Traditional cider apples have attributes that provide important and noteworthy characteristics to the resulting cider. These attributes include sweetness (naturally provided through sugars and sugar-alcohols, such as sorbitol), sharpness (due to organic acids, predominantly malic acid), bitterness and astringency (an effect of tannins and other polyphenolic compounds), and flavors (provided by volatile aromatic compounds). Hard cider can be made using a single cultivar that contains all of these attributes, or by blending juice from two or more cultivars, each with a subset of attributes. Certain apples currently intended for fresh-market use (e.g., 'Honeycrisp' and 'GoldRush') can be very sweet and/or high in acids, and can provide these attributes to cider blends. Specialty cider apples as well may contain exceptionally high levels of sugars and/or acids, but can additionally contribute unique flavors and tannins Some cider apples (e.g., 'Fillbarrel' and 'Harrison') contain up to 10-fold higher polyphenol concentrations than fresh-market apples (Thompson-Witrick et al., 2014; Valois et al., 2006).

In regions with a long history of cider production, hundreds of apple cultivars have been selected for use in hard cider over the centuries. For example, the Herefordshire Pomona (Bull et al., 1876), a catalog of apple and pear cultivars grown in England in the late 19th century, describes $\approx 80$ cider cultivars. Modern catalogs list 160 cider cultivars grown in the western counties of England and 300 in France (Boré and Fleckinger, 1997; Copas, 2013). Even greater diversity can be found in the ciderproducing regions of Spain, including Asturias and the Basque region, where more than 400 cider cultivars have been recognized (Dapena de la Fuente and Blázquez Noguero, 2009).

This diversity of cider cultivars has historically allowed for the production of different styles of cider, in regions with distinct growing environments. However, cider producers and nurseries in the United States are now currently challenged by the need to choose cultivars with the greatest chance of success, especially within a given region. Specialty cider cultivars have been selected for their fruit and juice qualities, but not necessarily for yield or ease of production. Thus, many cultivars may be challenging to grow, due to such drawbacks as disease susceptibility, biennial bearing, premature fruit drop, and excessive vegetative growth (Moulton et al., 2010; Rothwell, 2012). Susceptibility to fire blight (Erwinia amylovora) is of paramount concern, as this has limited production with European cultivars, at least in the eastern United States (Rothwell, 2012). Traditional European cider cultivars were selected in areas with climates and pathogens very different from those found in much of the United States. They were also selected for ground harvesting, and so preharvest fruit drop was often deemed to be a desirable trait. However, in the United States, most cider apples are currently being harvested from the tree. The growth, physiology, and juice quality of a given genotype also can be strongly influenced by environment (Alexander et al., 2016b), further challenging cultivar selection.

For this reason, there has been a proliferation of cider cultivar trials 
throughout the United States, including numerous regional projects funded in 2018 by the U.S. Department of Agriculture (USDA) Specialty Crop Block Program in Georgia, Michigan, New Mexico, Ohio, and West Virginia (USDA, 2018). In Michigan, the Great Lakes Cider Apple Collection contains 60 potentially superior cultivars, and is replicated across five diverse growing areas of Michigan including the short growing season Upper Peninsula (USDA Zone 4b). However, these projects will likely take at least 5 years to yield reproducible and reliable fruit yields and 10 years until useful recommendations can be made. An alternative to implementing and studying new live collections is to identify potentially superior cider cultivars through analyses of previously cataloged phenotypic data. The WSU Cider Web database (WSU, 2017) includes measurements collected at NWREC from 2002 to 2018 for 65 heritage cider apples from England and France, as well as historical American cultivars (Miles et al., 2017). The database includes 1) juice characteristics: tannin and acidity concentration, $\mathrm{pH}$, specific gravity, and TSS; 2 ) tree characteristics: bloom and harvest dates, bloom density rating, fruit productivity rating, juice yield, disease susceptibility, and tree vigor and growth habit; and 3 ) sensory evaluation of ciders produced from individual cultivars as evaluated by professional cider makers. Even more extensive and organized information on apple phenotypic traits is cataloged by the USDA National Plant Germplasm System. These data were compiled by long-term observation of more than 1000 cultivars (not only cider cultivars) maintained in Geneva, NY. Through analysis of cataloged data and observations of existing live collections, Peck et al. (2016) at Cornell University have identified more than 300 cultivars with potential for hard cider production, and are currently evaluating their juice quality and disease resistance. Their goal is to identify cultivars that have desirable and unique juice quality but that are also productive in modern orchard systems.

\section{Genetics and cultivar improvement}

Although the identification of regionally adapted cultivars will be a major step forward, cultivar improvement through breeding will likely be needed to produce cider cultivars optimized for North American growing conditions and evolving markets. Apple breeding programs generally focus on fresh-market apple. Many of the breeding goals of these programs, including disease and stress resistance, rootstock compatibility, and bearing habit, are also obviously important for cider apple. Although some breeding efforts have fortuitously resulted in apples with high sugar and/or high acids that are suitable for blending in hard cider, these programs select against many traits beneficial for hard cider. For example, the tannins that lend mouthfeel to a cider after fermentation and stabilize it during storage are perceived as bitter and render fruit unpalatable when eaten fresh. Very high acid content also is not desirable in fresh-market cultivars. Conversely, many traits beneficial for fresh-market apples have little importance for cider apples (e.g., large fruit size, red skin color, and resilience to cosmetic defects).

To date, breeding programs focusing on cider cultivars have been limited. Possibly the most famous cider apple breeding program was started in England at the Long Ashton Research Station (LARS) near Bristol, United Kingdom. In the early part of the 20th century, LARS conducted extensive cultivar trials and fermentation studies. These data provided phenotypic information needed for parental selection. A series of cultivars was released in 2008, with many of the selections named after women who worked in the U.K. cider industry (Copas, 2013). These LARS selections were the progeny of crosses between 'Dabinett' or 'Michelin' with 'James Grieve' or 'Worcester Pearmain'. The idea was to cross one of the two most commonly grown cider apples with an apple that had high juice yield and then select for offspring that ripened earlier than most of the commercially grown cider cultivars. Unfortunately, LARS closed in 2003 and the breeding program ceased. In France, the Institut National de la Recherche Agronomique is both developing new cider cultivars and licensing grower-developed selections. Many of these are less susceptible to fire blight, making them highly desirable for the U.S. cider industry. The Servicio Regional de Investigación y Desarrollo Agroalimentario in Asturias, Spain, has also started a breeding program focused on disease and pest resistance (Dapena and Blázquez, 2004).

Cider apple breeding efforts in the United States comprise limited, academic, and cooperative projects. At WSU, the student-run Palouse Wild Cider Breeding Project seeks not only to produce improved cider cultivars, but also to generate breeding material for similar efforts elsewhere (Courtney and Mullinax, 2018). At MSU, the Michigan PureRed breeding program is developing red-juiced apple cultivars for commercial apple juice and juice products, including hard cider. This effort is currently evaluating more than 120 distinct populations, many of which introgress germplasm from ornamental crabapple (Malus sp.). The Midwest Apple Improvement Association, a cooperation between The Ohio State University and growers in the midwestern states, is also evaluating selections for potential cider use in collaboration with MSU (Miller and Miller, 2017).

Although these efforts will generally require many years to introduce superior cider cultivars, advances in plant breeding approaches and techniques are being accelerated and may greatly reduce this time (van Nocker and Gardiner, 2014). An important first step is to map and identify the genetic loci that collectively contribute to cider-specific traits. This requires phenotypic evaluation of individuals in a genetically related population segregating for the traits of interest (linkage mapping), or a large number of individuals representing diverse genetic backgrounds (mapping by association). Advances in molecular marker development in apple in the past 5 years (Bianco et al., 2014, 2016), and the release of a high-quality reference genome (Daccord et al., 2017) should facilitate further genetic analyses and breeding. Results generated from high-resolution genotyping can be integrated into breeding programs to enhance parental selection and enable selection of breeding stock or potentially elite cultivars at the seedling stage.

There has been some success with integrating fine-mapped quantitative trait loci (QTL) for fresh-market oriented traits in apple (reviewed by Ru et al., 2015), such as the $M a$ locus that influences acidity (Maliepaard et al., 1998; Xu et al., 2012). Verdu et al. (2014) used molecular markers 
to identify more than 60 QTLs contributing to polyphenol content in apple (Chagné et al., 2012). Leforestier et al. (2015) used single-nucleotide polymorphisms to identify 17 genetic regions that influence the differences between cider apples and fresh-market apples. However, in both cases, the identified regions were too numerous and/or were too large to be easily used in targeted breeding.

The nascent technique of genomic selection (GS) provides an exciting opportunity for cider apple breeding. GS uses markers across the whole genome to predict which crosses will yield the most desirable progeny. GS has been used in apple breeding with promising results, even for traits that show low heritability (Kumar et al., 2012a, 2012b).

\section{Perspectives}

The renaissance of the cider apple industry in the United States in the past decade provides exciting opportunities for current and prospective apple growers and cider producers, but also presents numerous and formidable challenges. Foremost among these is the need to accurately predict the volume of specialty cultivars that the industry will require at least 10 years before new plantings become profitable. This will be driven not only by the market for cider in general, but by consumer tastes, which to date have been satisfied with ciders made largely from fresh-market apples.

If production of specialty cultivars is required to sustain the growth of the industry, research-based information is needed to enable a reliable and affordable supply of domestically produced cider-specific apples. It remains to be determined whether the highly structured and expensive orchard designs that enable intensive and profitable production of high-quality freshmarket fruit are beneficial for profitable production of cider cultivars. Orchard design may be primarily driven by the evolution of mechanical pruning and harvesting approaches. Shake-andsweep approaches with free-standing trees may be most suitable if food safety procedures are implemented to allow for recovery of fruit from the ground. Otherwise, shake-and-catch techniques will likely require medium- to highdensity plantings with minimal height $(10-12 \mathrm{ft})$ to allow for over-the-row machinery. Precision fruit harvesting using full artificial intelligence-based or avatar-based approaches will likely also require highly uniform growth that is typically only achieved in intensive production systems.

The type of production systems that are developed will strongly influence cultivar choice and development of new cultivars. High-density plantings require dwarfed trees and scion-rootstock compatibility, which is not always observed with apple cultivars, and so the genetic factors influencing compatibility need to be identified. Harvesting by shaking requires that mature fruit separates easily from the tree, whereas precision harvesting requires that fruit be retained. Although domestic apple and its wild relatives (Malus sp.) exhibit interesting natural variation for fruit abscission (Sun et al., 2009), genetic loci influencing this trait have not been mapped or identified. Precision harvesting will also require markers of maturity that are easily assessed and interpreted computationally, such as loss of chlorophyll in the skin.

Although some progress has been made to map and identify cider-specific traits in apple, further challenges remain. Linkage mapping has so far relied on populations originally designed to map traits important for fresh-market fruit quality, and may not be suitable for fine mapping of traits, such as phenolics content or flavor attributes that withstand fermentation. Thus, informative populations need to be developed as quickly as possible. Testing these populations across diverse regions of the United States will enable assessment of the influence of environment on these traits. Although association mapping avoids this hurdle, it often relies on phenotypic information generated from single individuals, often at a single pass and in a high-throughput manner. As genomic technologies continue to gain resolution, additional effort focused on precision phenomics, especially with respect to biochemical qualities of the juice, may be beneficial. Of utmost importance to this goal is the evaluation of cider cultivars in diverse regions, and the continued maintenance of potentially useful accessions in the large USDA apple germplasm live collection.

Collectively, cider-related research in the United States and elsewhere has provided important information for cider apple growers and producers. However, these studies have focused on specific aspects of the industry in limited geographic regions of the United States. Truly integrative research recognizing opportunities and limitations in the economic, horticultural, and technological aspects of cider apple production will support the anticipated growth of the hard cider industry into the coming decades.

\section{Literature cited}

Alexander, T.R., J. King, E. Scheenstra, and C.A. Miles. 2016a. Yield, fruit damage, yield loss and juice quality characteristics of machine and hand harvested 'Brown Snout' specialty cider apple stored at ambient conditions in northwest Washington. HortTechnology 26:614619.

Alexander, T.R., J. King, A. Zimmerman, and C.A. Miles. 2016b. Regional variation in juice quality characteristics of four cider apple (Malus $\times$ domestica Borkh.) cultivars in northwest and central Washington. HortScience 51:1498-1502.

Alexander, T.R., C.F. Ross, E.A. Walsh, and C.A. Miles. 2018. Sensory comparison of ciders produced from machine- and hand-harvested 'Brown Snout' specialty cider apples stored at ambient conditions in northwest Washington. HortTechnology 28:35-43.

Alexander, T.R., E. Scheenstra, J. King, S. Musacchi, and C.A. Miles. 2019. Establishing a cider apple orchard for mechanized management. Washington State Univ. Ext. Publ. EM117E.

Bianco, L., A. Cestaro, D.J. Sargent, E. Banchi, S. Derdak, M. Di Gaurdo, S. Salvi, J. Jansen, R. Viola, I. Gut, F. Laurens, D. Chagné, R. Velasco, E. van de Weg, and M. Troggio. 2014. Development and validation of a $20 \mathrm{~K}$ single nucleotide polymorphism (SNP) whole genome genotyping array for apple (Malus $\times$ domestica Borkh.). PLoS One 9:el10377.

Bianco, L., A. Cestaro, G. Linsmith, H. Muranty, C. Denancé, A. Théron, C. Poncet, D. Micheletti, E. Kerschbamer, E.A. Di Pierrro, S. Larger, M. Pindo, E. Van de Weg, A. Davassi, F. Laurens, R. Velaso, C.E. Durel, and M. Troggio. 2016. Development and validation of the Axiom ${ }^{\circledR}$ Apple480K SNP genotyping array. Plant J. 86:62-74.

Boré, J.M. and J. Fleckinger. 1997. Pommiers à cidre: Variétés de France. Institut National de la Recherche Agronomique (INRA), Paris, France. 
Bull, E.G., H.G. Bull, A.B. Ellis, and R. Hogg. 1876. Herefordshire pomona. Jakeman and Carver, Hereford, UK.

Chagné, D., R.N. Crowhurst, M. Troggio, M.W. Davey, B. Gilmore, C. Lawley, S. Vanderzande, R.P. Hellens, S. Kumar, A. Cestaro, R. Velasco, D. Main, J.D. Rees, A. Iezzoni, T. Mockler, L. Wilhelm, E. Van de Weg, S.E. Gardiner, N. Bassil, and C. Peace. 2012. Genome-wide SNP detection, validation, and development of an 8K SNP array for apple. PLoS One 7:e31745.

Copas, L. 2013. Cider apples: The new pomona. Short Run Press, Exeter, UK.

Courtney, R. and T. Mullinax. 2018. WSU reveals its wild cider: Students start cider apple breeding program to learn techniques. Good Fruit Grower 69(6):12-15.

Daccord, N., J.M. Celton, G. Linsmith, C. Becker, N. Choisne, E. Schijlen, H. van de Geest, L. Bianco, D. Micheletti, R. Velasco, E.A. Di Pierro, J. Gouzy, D.J.G. Rees, P. Guérif, H. Muranty, C. Durel, F. Laurens, Y. Lespinasse, S. Gaillard, S. Aubourg, H. Quesneville, D. Weigel, E. van de Weg, M. Troggio, and E. Bucher. 2017. High-quality de novo assembly of the apple genome and methylome dynamics of early fruit development. Nat. Genet. 49:1099-1106.

Dapena, E. and M.D. Blázquez. 2004. Improvement of the resistance to scab, rosy apple aphid and fire blight in a breeding programme of cider apple cultivars. Acta Hort. 663:725-728.

Dapena de la Fuente, E. and M.D. Blázquez Noguero. 2009. Descripción de las variedades de manzana de la D.O.P. sidra de Asturias. Servicio Regional de Investigación y Desarrollo Agroalimentario (SERIDA), Villaviciosa, Spain.

Degenhard, J. 2019. Alcoholic drinks report 2019 - Cider, perry and rice wine. Statista Rpt. 48819. 1 Apr. 2019. <https://www. statista.com/study/48819/alcoholicdrinks-report-cider-perry-and-rice-wine $/>$.

Economics Policy Institute. 2019. Minimum wage tracker as of 8 Jan. 2019. 1 May 2019. <https://www.epi.org/minimumwage-tracker $/>$.

Ewing, B., G. Peck, S. Ma, A. Neilson, and A. Stewart. 2019. Management of apple maturity and postharvest storage conditions to increase polyphenols in cider. HortScience 54:143-148.

Ewing, B.L. and B.A. Rasco. 2018. Food safety modernization act produce safety rule compliance for United States hard cider producers using ground-harvested apples. HortTechnology 28:698-705.

Farris, J.G., G.M. Peck, and G.E. Groover. 2013. Assessing the economic feasibility of growing specialized apple cultivars for sale to commercial hard cider producers. Virginia Coop. Ext. Pub. AREC-46P.

Fitzgerald, J., A. Berrie, C. Jay, L. Copas, H. Worle, G. Arnold, and J. Thatcher. 2013. Developing cider orchards for modern cider production. Asp. Appl. Biol. 111:1-3.

Galinato, S., R.K. Gallardo, and C.A. Miles. 2014. 2013 Cost estimation for establishing a cider apple orchard in western Washington. Washington State Univ. Ext. Publ. FS141E.

Galinato, S., C.A. Miles, and T.R. Alexander. 2016. Feasibility of different harvest methods for cider apples: Case study for western Washington. Washington State Univ. Ext. Publ. TB32.

Galinato, S. and C.A. Miles. 2016. 2015 Cost estimates of establishing and producing specialty cider apples in central Washington. Washington State Univ. Ext. Publ. TB35.

Gottschalk, C., N. Rothwell, and S. van Nocker. 2017. Apple cultivars for production of hard cider in Michigan. Michigan State Univ. Ext. Bul. E3364.

Klonsky, K.M. and D. Stewart. 2014. 2014 sample costs to produce processing apples. 1 Nov. 2019. <https://coststudyfiles.ucdavis. edu/uploads/cs_public/9c/bf/9cbfcb79c037-47fe-af0b-79ec2edb4031/applessanta-cruz-conv-processing.pdf>.

Kumar, S., M.C.A.M. Bink, R.K. Volz, V.G.M. Bus, and D. Chagné. 2012a. Towards genomic selection in apple (Malus $\times$ domestica Borkh.) breeding programmes: Prospects, challenges and strategies. Tree Genet. Genomes 8:1-14.

Kumar, S., D. Chagné, M.C.A.M. Bink, R.K. Volz, C. Whitworth, and C. Carlisle. 2012 b. Genomic selection for fruit quality traits in apple. PLoS One 7:e36674.

Lea, A.G.H. and F.W. Beech. 1978. The phenolics of ciders: Effect of cultural conditions. J. Sci. Food Agr. 29:493-496.

Leforestier, D., E. Ravon, H. Muranty, A. Cornille, C. Lemaire, T. Giraud, C.E. Durel, and A. Branca. 2015. Genomic basis of the differences between cider and dessert apple varieties. Evol. Appl. 8:650661.

Ma, S., A. Neilson, J. Lahne, G. Peck, S. O'Keefe, E.K. Hurley, A. Sandbrook, and A. Stewart. 2018. Juice clarification with pectinase reduced yeast assimilable nitrogen in apple juice without affecting the polyphenol composition in cider. J. Food Sci. 83:2772-2781.

Maliepaard, C., F.H. Alston, G. van Arkel, L.M. Brown, E. Chevreau, F. Dunemann, K.M. Evans, S. Gardiner, P. Guilford,
A.W. van Heusden, J. Janse, F. Laurens, J.R. Lynn, A.G. Manganaris, A.P.M. den Nijs, N. Periam, E. Rikkerink, P. Roche, C. Ryder, S. Sansavini, H. Schmidt, S. Tartarini, J.J. Verhaegh, M. Vrielink-van Ginkel, and G.J. King. 1998. Aligning male and female linkage maps of apple (Malus pumila Mill.) using multi-allelic markers. Theor. Appl. Genet. 97:60-73.

Merwin, I.A. 2015. Growing apples for craft ciders. New York Fruit Qrtly. 23(1):5-9.

Miles, C.A., J. King, T.R. Alexander, and E. Scheenstra. 2017. Evaluation of flower, fruit, and juice characteristics of a multinational collection of cider apple cultivars grown in the U.S. Pacific northwest. HortTechnology 27:431-439.

Miles, C.A. and J. King. 2014. Yield, labor, and fruit and juice quality characteristics of machine and hand-harvested 'Brown Snout' specialty cider apple. HortTechnology 24:519-526.

Miles, C. 2017. Cost effective technologies for cider apple orchard mechanization and fruit quality evaluation, p. 4. In: Washington State Dept. Agr. Specialty Crop Block Grant Awards 2017. 1 Apr. 2019. <https://cms. agr.wa.gov/WSDAKentico/Documents/ AdminSvcs/SCBG/2017AwardAbstractsWeb. pdf?/2017AwardAbstractsWeb>.

Miller, A. and D. Miller. 2017. Ohio cider: Blending tradition and discovery for the modern market, p 14. In: The Ortet. Midwest Apple Improvement Assn., Newcomerstown, $\mathrm{OH}$.

Moulton, G.A., C.A. Miles, J. King, and A. Zimmerman. 2010. Hard cider production and orchard management in the Pacific northwest. Pacific Northwest Ext. Publ. PNW 621.

Mpelasoka, B., M.H. Behboudian, and T. Mills. 2001. Water relations, photosynthesis, growth, yield and fruit size of 'Braeburn': Responses to deficit irrigation and crop load. J. Hort. Sci. Bio. 76:150-156.

Pashow, L. and M. Mahr. 2018. Hard cider supply chain analysis. 1 Apr. 2019. <https://harvestny.cce.cornell.edu/ uploads/doc_48.pdf>.

Peck, G.M., M.N. McGuire, T.F. Boudreau, and A.C. Stewart. 2016. Crop load density affects 'York' apple juice and hard cider quality. HortScience 51:1098-1102.

Peck, G. and W. Knickerbocker. 2018. Economic case studies of cider apple orchards in New York state. New York Fruit Qrtly. 26(3):5-10.

Robinson, T., S. Hoying, M.M. Sazo, A. DeMarree, and L. Dominguez. 2013. A vision for apple orchard systems of the future. New York Fruit Qrtly. 21(3):11-16. 
Root, W.H. and D.M. Barrett. 2005. Apples and apple processing, p. 455-480. In: D.M. Barrett, L. Somogyi, and H. Ramaswamy (eds.). Processing fruits science and technology. 2nd ed. CRC Press, Boca Raton, FL.

Rothwell, N. 2012. Hard cider varieties suitable for northern Michigan. I May 2019. <https://www.canr.msu.edu/ uploads/files/Research_Center/NW_ Mich_Hort/Training_Pruning_Varities/ HardCiderVar2012Expo.pdf>.

Ru, S., D. Main, K. Evans, and C. Peace. 2015. Current applications, challenges, and perspectives of marker-assisted seedling selection in Rosaceae tree fruit breeding. Tree Genet. Genomes 11:1-12.

Statista. 2018. Consumers of cider in the United States 2018, by age. 1 Apr. 2019. <https://www.statista.com/statistics/ 228267 /strong-cider-consumption-usa/>.

Statista. 2019a. Alcoholic drinks, revenue growth - Worldwide. 1 Apr. 2019. <https://www.statista.com/outlook/ $10000000 / 100 /$ alcoholic-drinks / worldwide\#market-globalRevenue> .

Statista. 2019b. Consumers of red wine in the United States 2018, by age. 1 Apr. 2019. <https://www.statista.com/ statistics $/ 228269 /$ wine-consumptionusa $/>$.
Statista. 2019c. Consumers of white wine in the United States 2018 , by age. 1 Apr. 2019. <https://www.statista.com/ statistics $/ 228338 /$ any-white-wineconsumption-usa/>.

Sun, L., P. Forsline, and S. van Nocker. 2009. Natural variation for fruit-abscissionrelated traits in apple (Malus). Euphytica 165:55.

Thompson-Witrick, K.A., K.M. Goodrich, A.P. Neilson, E.K. Hurley, G.M. Peck, and A.C. Stewart. 2014. Characterization of the polyphenol composition of 20 cultivars of cider, processing, and dessert apples (Malus $\times$ domestica Borkh.) grown in Virginia. J. Agr. Food Chem. 62:1018110191.

Tozer, P.R., S.P. Galinato, C.F. Ross, C.A. Miles, and J.J. McCluskey. 2015. Sensory analysis and willingness to pay for craft cider. J. Wine Econ. 10:314-328.

Unuk, T., S. Tojnko, Z. Cmelik, and M. Stopar. 2006. Polyphenol content in apple fruits as affected by crop load and rate of applied nitrogen. Acta Hort. 721:173176.

U.S. Department of Agriculture (USDA). 2018. Transportation and marketing specialty crop block grant program: Fiscal year 2018 description of funded projects.
3 May 2019. <https://www.ams.usda. gov/sites / default/files / media/ 2018SCBGPGrantstotheStates.pdf>.

U.S. Food and Drug Administration. 2001. Hazard analysis and critical control point (HACCP); Procedures for the safe and sanitary processing and importing of juice. Federal Rule 66 FR 6137. U.S. Food and Drug Administration, Washington, DC.

Valois, S., I.A. Merwin, and O.I. PadillaZakour. 2006. Characterization of fermented cider apple cultivars grown in upstate New York. J. Amer. Pomol. Soc. 60:113-128.

van Nocker, S. and S.E. Gardiner. 2014. Breeding better cultivars, faster: Applications of new technologies for the rapid deployment of superior horticultural tree crops. Hort. Res. 1:14022.

Verdu, C.F., S. Guyot, N. Childebrand, M. Buhat, J.M. Celton, S. Gaillard, P. Lasserre-Zuber, M. Troggio, D. Guilet, and F. Laurens. 2014. QTL analysis and candidate gene mapping for the polyphenol content in cider apple. PLoS One 9:e107103.

Washington State University. 2017. WSU cider: Cultivar performance gallery. 1 May 2019 . <https://cider.wsu.edu/ ciderweb $/>$.

$\mathrm{Xu}, \mathrm{K} ., \mathrm{A}$. Wang, and S. Brown. 2012. Genetic characterization of the Ma locus with $\mathrm{pH}$ and titratable acidity in apple. Mol. Breed. 30:899-912. 